\title{
A Study of Locke's Thought of Pluralism and Unity
}

\begin{tabular}{|c|c|}
\hline 10ol of Hist & , China \\
\hline $\begin{array}{c}\text { Article History } \\
\text { Received: } 22.07 .2020 \\
\text { Accepted: } 12.08 .2020 \\
\text { Published: } 17.10 .2020 \\
\\
\text { Journal homepage: } \\
\text { https://www.easpublisher.com/easjehl } \\
\end{array}$ & 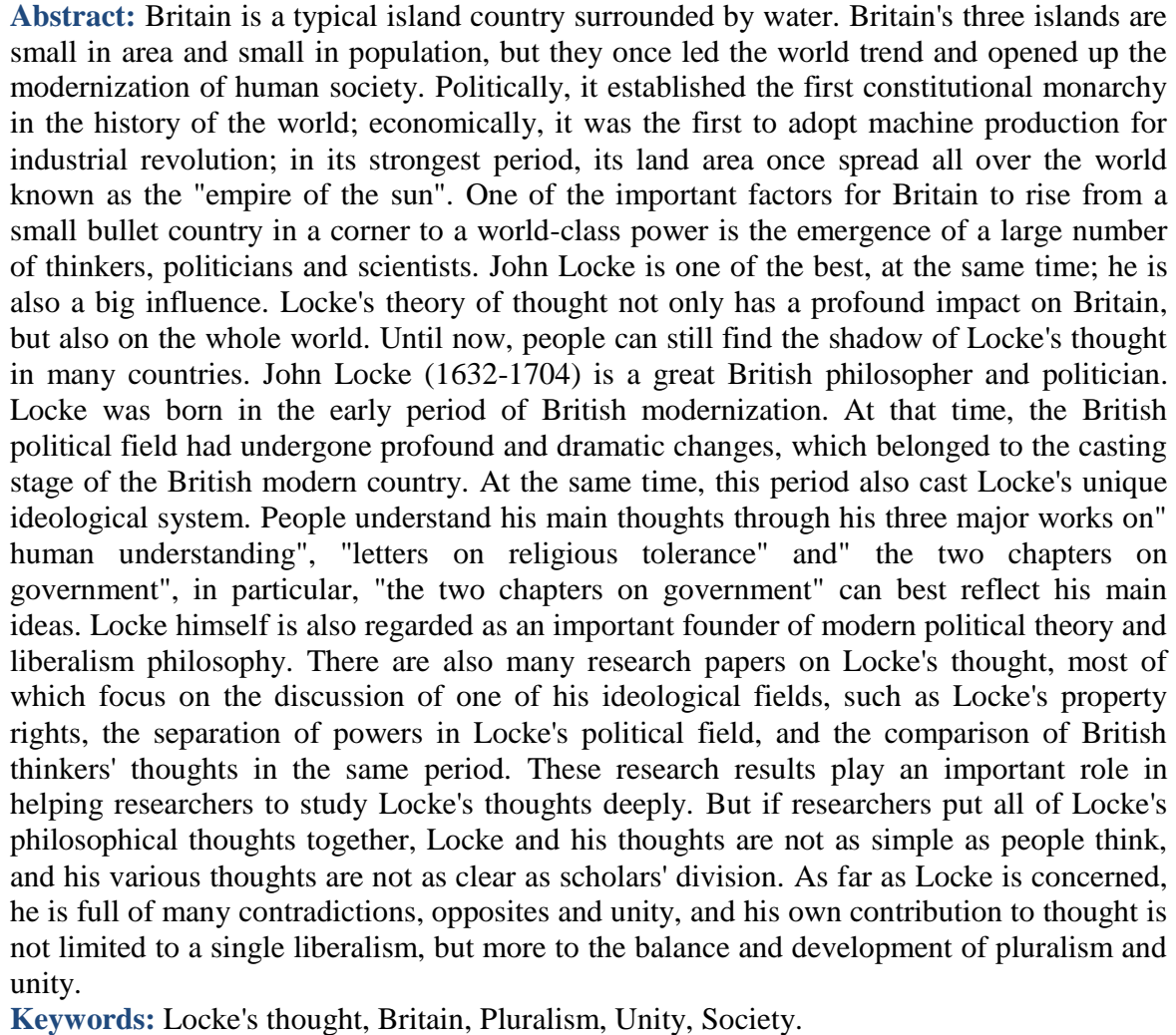 \\
\hline
\end{tabular}

Copyright () 2020 The Author(s): This is an open-access article distributed under the terms of the Creative Commons Attribution 4.0 International License (CC BY-NC 4.0) which permits unrestricted use, distribution, and reproduction in any medium for non-commercial use provided the original author and source are credited.

\section{INTRODUCTION}

Locke's works involve a wide range of philosophy, including political, religious, economic and educational. In summary, its main ideological content can be summarized as the following key words: natural state, property rights, liberalism, social contract theory and limited government theory. Logically, these key words are not isolated from each other, but linked to each other. They together describe the formation process of national authority and how to restrict it. Locke's logical starting point is the property right in the natural state. Property right is a natural right of human beings and cannot be deprived at will. In a broad sense, freedom includes human life and freedom. All people have the freedom of life. Private property rights are the basic guarantee of freedom [1]. Before the government came into being, people lived in a state of high freedom. Because natural law constructs a basic order for human society in natural state. It ensures that this natural state is a state in which individuals can be equal and free. However, there are various inconveniences in this natural state, such as: the natural law is handed over to each person to implement, and each person's understanding of the natural law is different, so it is easy to deviate from the implementation. In the human society, there are always some people who can not strictly obey the principles of fairness and morality and infringe upon others. Natural law itself has no coercive power. As a result, the freedom of others can be threatened by danger and damage [2]. In order to overcome the defects in the natural state, people have to give up part of their rights and make contracts with each 
other, which lead to the emergence of the government and the state.

\section{Analysis}

From the perspective of the development process of rights, political power is not innate, so it is not an absolute and arbitrary right to dominate the lives and properties of others. It is their right to make laws. In order to ensure that the rights of the government are not abused and infringed upon the civil liberties, on the one hand, Locke restricted the rights of the government and put forward a limited theory of government, limiting the rights with rights. On the other hand, it gives the people the right to participate in politics and the right to revolution, so as to restrict and control the government. In short, property is the guarantee of freedom, freedom is the premise of contract, and contract is the cause of government. This eventually led to the decentralization of government. In Locke's whole thought, property and freedom are his main ideas, so there is no doubt that Locke is the founder of liberalism and empiricism. This is only a simple surface combing. If scholars further explore the essence and relationship of Locke's thoughts, Locke's thoughts are far less single and simple than on the surface. In order to guarantee individual freedom, the individual transfers part of the right of freedom to the government. The power of the individual relative to the government is relatively weak. The government has the legitimacy by signing a contract with the individual. Therefore, the government has the responsibility to maintain the personal property and freedom. When tyranny comes to threaten personal property and freedom, people can overthrow it by means of revolution, because the government at that time has violated the previous social contract, which seems to be very common now, but it is appalling to Britain and even the world at that time. At that time, most of the countries were monarchy or even autocracy, and they believed that "the monarchy is the God's representative in the world". To oppose the government is to oppose the monarch. To oppose the monarch is to violate the will of God. In this political background, Locke's contention for "the grant of monarchy and the people" is very forward-looking and radical, after his death, his radical ideas were adopted and practiced by the later enlightenment.

But on the other hand, Locke showed a conservative side. Conservatism is not necessarily behaving as something backward. It has two distinct characteristics: steadiness, honesty and timely change. Therefore, conservatism played an important role in British history. Locke's conservatism is embodied in the following aspects: first, Locke gives people the right to revolt against tyranny, because this kind of behavior is people's "appeal to heaven", but when talking about this form of revolt, he does not advocate that people overthrow the government by means of violence, and suggests that people should carry out bloodless revolution. From the perspective of Locke's opposition between violence and revolution, the choice of peaceful revolution should have its special significance. In addition, the conservative side of Locke's thought is reflected in his strong religious color and his theoretical foundation is based on theology. For example, when Locke talked about the source of private property rights, he mentioned that "God gave the earth to all mankind and established private ownership"[3], that is to say, Locke believes that people have private property and freedom because it is a right given by God. In 1695, Locke also published "the rationality of Christianity". In the first half of this book, he discussed what the true Christian belief is; in the second half, he explained the rationality of "the law of believing in God can be saved", and once again explained the complementarity of rationality and belief in the theory of understanding [4]. Locke's rationality is defined as "people provide the final judgment and guide on all issues". Rational thought is connected with science, and faith is connected with God. Therefore, in reality, people generally believe that reason is relative, and Rock creatively combines reason and belief. He thinks reason is natural revelation. Inspiration is natural rationality extended after many new discoveries. People have rational grounds to prove that they come from God. A person has a strong rational thought; he is sure that Christianity is right, at this time; Locke connected science with religion and became a devout Christian. Second, in this part of the content of property rights, Locke advocates that individuals obtain private property through labor to maintain their own life and guarantee their freedom.

This view and capitalism constitute the economic basis for the development of capitalism. In the early stage of capitalism, the inviolability of private property was used as a theoretical weapon to attack the church and the feudal monarch who violated and deprived others' private property at will to make them rich and lead a luxurious life. Therefore, Locke is regarded as the spokesman of capitalism, and he is also a strong supporter of the inviolability theory of private property. But people can find another side of Locke's view of property. Locke thinks that in the natural state, God gives human the basic right of existence. In order to make human survive, all natural things belong to human individuals equally rather than individual characters. That is to say, the property right belongs to all the people before labor. He admits that the private property originates from the public property. On this basis, Locke further points out that the state has the right to regulate property. At the same time, there are several restrictions on excessive private property rights. That is to say, "there is enough good left for others" and "the amount of property acquired". As a matter of fact, it is to occupy private property through labor, at the same time, enough survival materials are left behind. Locke opposed personal luxury, waste and the widening 
gap between the rich and the poor, and supported the redistribution of products to achieve the balance of wealth [6]. Based on the above results, these contents have the color of building a mixed economy in a welfare state and the thoughts of republicanism and socialism. He combined property private ownership, common ownership, republicanism and capitalism organically, instead of the single ideological content of capitalist private economy. As these ideas first appeared in the 17th century England, some of them were not mature, and the system was not complete. But from the background of the times, Locke's economic thoughts of pluralism and unity were quite advanced at that time. To sum up, in political thought, Locke's thought is both conservative and radical. Locke's thought has both scientific rationality and religious belief. In the economic thought, it not only shows the capitalist tendency of safeguarding the private property rights, but also shows the concern about the common property. The republicanism tendency of the distribution problem has obvious characteristics of diversification. So how does Locke's idea of pluralism and unity come into being? Generally speaking, the formation of ideologist's thought is closely related to his era background and growth experience. Locke's thought is not produced out of nothing, but the product of the era, the crystallization of personal continuous practice and thinking.

\section{The foundation and background of Locke's pluralism}

Social factors: from the point of time, the historical period of Locke's life can be divided into three stages. The first stage was before the English Revolution in 1640. With the establishment of the new Stuart dynasty, the contradictions among various political and religious forces in China have intensified. The royal family of Scotland is a Catholic monarchy, the Anglican Church is Puritan, and the native English church is Anglican, this led to the British civil war. The second stage was the civil war and the restoration of Stuart dynasty. At this time, the British political situation was turbulent and the regime changes. Until the restoration of the Stuart dynasty, all factions temporarily reconciled, but the political and religious contradictions in Britain were still sharp. The third stage is mainly around the glorious revolution. James II was determined to restore the authority of Catholicism in England, which intensified the contradiction again. This makes the two factions fighting with each other in the parliament unite again to carry out the "Glorious Revolution" and issue the bill of rights to consolidate the revolutionary achievements. It can be seen that Locke lived in an age full of turbulence, and the political chaos caused by religious contradictions ran through all the time. Locke hopes to find religious and political reconciliation from the chaos, and find reconciliation among various religious factions. So there is the Locke religion which combines belief and reason. At the same time, Locke lived in an age full of change. The Renaissance and religious reform have been carried out successively, the Enlightenment has begun, and science and technology have made breakthroughs. Under this trend, Britain also completed the religious reform, and the humanist and rational thought gradually became the mainstream of society. The purpose of these changes is not to oppose religious belief, but to oppose the decadent Catholic Church. As a result, the Church of England lost its national political rights, and the religious belief was still preserved. That's why Locke believed in Christianity while advocating rationality, because he knew that religion could cure people's fallen souls.

\section{Economic factors}

Locke's diversification is also reflected in his economic thought. The British economy during the Stuart dynasty was also in the agricultural society in the period of transformation to the industrial society. The prosperity and unification of Tudor dynasty promoted the development of British economy and made the population of the new dynasty grow continuously. In the early days of Stuart, the population grew faster than the grain [7]. As a result, the rapid growth of population has promoted the rise of prices. The enclosure movement became more and more intense, which led to the increase of refugees and the prevalence of unemployment. With the outbreak of civil war, the huge military expenditure and the extravagant waste of royal life made the royal family not pay for its financial input. The only way to solve this problem is to increase taxes. The tax increase solved some financial problems of the royal family, but it resulted in a heavier burden on the people at the bottom of the family and a poorer life, which led to sharp class contradictions and people's dissatisfaction with the king. In addition, previously, economic problems that are difficult to solve in the economic field have increased the pressure of poverty on society. With the emergence of the disadvantages brought about by the development of capitalist economy, Locke tried to restrict private property rights and give the state the right to regulate property; Locke hoped to explore ways to overcome the widening gap between the rich and the poor in capitalist society, which was a real problem threatening social stability. This laid a theoretical foundation for the establishment of capitalist welfare state.

\section{Personal experience}

Locke's life experience was rich and varied. His early life was relatively quiet. After finishing his studies, he taught at Oxford University. During his teaching, he traveled to Germany. After returning to China, he began to engage in medical practice and met with British politicians to enter the British political arena. Then he began to write books. During his writing, he went to France for cultivation because of chronic respiratory diseases. After returning home, he stepped into British politics again, and was exiled to 
Holland by the restored government due to political differences. During these five years, Locke lived in hiding and had plenty of time to write. After the glorious revolution, Locke returned to England to continue his studies in politics, economics and philosophy. In his later years, he quitted his job and concentrated on commenting on Paul's letters [8]. Rich life experience and overseas experience made Locke get to know well-known politicians, philosophers, theologians and scientists in Europe at that time, and increased and expanded Locke's knowledge and knowledge. He was good at philosophy, politics, religion, science and medicine. It is these rich experiences and extensive knowledge that make Locke not only pay attention to one aspect of content in his research process, but also lay a solid theoretical foundation for the formation of diversified thoughts in the future. In addition, Locke lived in a turbulent period of civil war in England. During this period, various political and religious factions fought fiercely. It can be seen from Locke's political experience. In this political environment, Locke, who was plagued by illness, was displaced, tortured and miserable. When the British civil war was turbulent, he wrote: "I found myself in a storm continued to this day, and I feel that I have survived" [9]. History has proved that there are many ways of revolution. They can be peaceful, violent or a combination of violence and peace. They have advantages and disadvantages. Why did Locke choose a peaceful way? Locke's painful life experience gives the answer.

Locke does not want to solve the problem in the way of confrontation and violence. He wants to complete the social transformation with the reconciliation of both sides of the conflict. The British revolution was finally solved in a basically peaceful way, which provided Locke with practical basis for operation.

This idea also runs through Locke's comprehensive absorption and inclusion of various ideas.

\section{Conclusions}

Unique social environment and life experience cast unique Locke thought. Locke combines these nearly opposite pluralistic thoughts to form his own unique ideological connotation. To a certain extent, this reflects that Locke is in a turbulent era full of contradictions, and he also lives in a turbulent era, which is an era of all kinds of ideas converging and colliding. Locke's thought is not limited to a certain field or a certain aspect. His thought has distinct characteristics of the times, His thought has distinct characteristics of the times, and also highlights Locke's infinite wisdom. Locke connected the medieval thought with the modern thought, and connected people from all walks of life in English society, which is different and diversified Locke.

\section{REFERENCES}

1. (British) John Locke's theory of government (Next chapter) [M]. (1964).Translated by Ye Qifang and Qu junong. Beijing: Commercial Press.

2. Mei, X. (1997). On Locke's view of property [J], Beijing: Journal of Beijing Normal University, 1: 100-107.

3. (U.S.) by Gretel Thomson, Yuan Yinchuan, translated by Cai, H. (2014). Locke [M]. Beijing: Zhonghua Book Company, 117.

4. (English) Locke, translated by Wang, A. (2006). The rationality of Christianity [M], Wuhan: Wuhan University Press.

5. (U.S.) by Greg foster, translated by sun Lizhong. (2017). Starting from Locke [M]. Harbin: Heilongjiang Education Press, 103.

6. (English) by John Locke, translated by Ye, Q., \& Qu, J. (1964). On government (Next chapter) [M]. Beijing: Commercial Press.

7. Qian, C., Xu, J. (2019). General history of Britain [M]. Shanghai: Shanghai Social Sciences Press, 151.

8. (U.S.) by Gretel Thomson. (2014). Translated by Yuan Yinchuan, and Cai Hongyan, Locke [M]. Beijing: Zhonghua Book Company, 1-16.

9. (U.S.) by Greg foster, translated by sun Lizhong. (2017). Starting from Locke [M]. Harbin: Heilongjiang Education Press, 2. 